\title{
Mobile Applications in Mastering Mining Engineers' Competences
}

\author{
Roman Islamov ${ }^{1, *}$, Oksana Greenwald $^{1}$, and Nina Tunyova ${ }^{1}$ \\ ${ }^{1}$ Kemerovo State University, Institute of Philology, Foreign Languages and Mediacommunications, \\ Department of Foreign Languages, 650000, 6 Krasnaya st., Kemerovo, Russia
}

\begin{abstract}
Being one of the leading coal mining regions in the world, Kuzbass (Russia) demands from its regional higher educational institutions to master a range of competences of the graduates, namely mining engineers. Foreign language competence is considered to be among the key ones. The article reveals the concept of the competence, its relevance for mining engineers. We also analyze existing mobile applications from the point of view of their educational potential and present the results of the experiment conducted to assess effectiveness of mobile applications in mastering foreign language competence of mining engineering undergraduates. Our methods included interviews with students, classroom observations and surveys of students. The results suggest that integrating mobile applications in educational process is likely to have a positive impact on foreign language competence and increase students' motivation and satisfaction with foreign language learning.
\end{abstract}

\section{Introduction}

The notion of competence appeared in the second half of the $20^{\text {th }}$ century, when a number of researches on the theory of management dealing with personal traits and characteristics of an employee, which contribute to his/her efficient fulfillment of professional duties and requirements, were conducted [1]. Furthermore, the term competence was introduced into education by David McClelland [2]. The $21^{\text {st }}$ century higher education standards worldwide describe the results of graduates' training in the terms of competences. In the USA the concept of competence is connected with personal characteristics, which determine one's advanced achievements in a particular professional activity. In the UK the opinion dominates that competence means a concordance of the results of any educational or professional activity with authorized standards. Along with European countries, Russia adheres to both behavioral and functional notions of competence [3].

According to Russian state standards of higher education, mining engineers are supposed to have both key competences, which are universal for every educated person, and professional competences specific for a particular profession. The list of key competences contains foreign language competence defined by the European Council as "communicating in a foreign language: ability to express and interpret concepts, thoughts,

\footnotetext{
* Corresponding author: r.islamov87@gmail.com
} 
feelings, facts and opinions both orally and in writing, also includes mediation skills (i.e. summarizing, paraphrasing, interpreting or translating) and intercultural understanding" [4].

The importance to master foreign language competence (mainly, in English) for mining engineers is evident. Over the past fifty years English has acquired the status of lingua franca in different spheres: medicine, education, culture, business, science, industry, etc. The existence of the single universal language offers new opportunities and prospects in these areas, simplifying and increasing the speed of exchange and dissemination of information, expands potential audience, promotes attractive realization of the professional purposes, etc. According to the data of Research Trends, this fact has predetermined the growth in the ratio of articles in English in comparison with articles in national languages in some countries since the beginning of the $21^{\text {st }}$ century. For example, this ratio in Russia was equal to 5:1 in 1990-s, increased five times more by 2011 and it is still growing now [5].

In spite of the fact that such situation, according to Joe Lo Bianco, shows "the progressive deterioration of competence in high-level discourses" or weakening in particular field of knowledge (the author uses the term "domain collapse" in relation to the language losing the competitive position) [6], the current indexation of scientific articles in English in Scopus makes more than $80 \%$ in comparison with other languages. This is over 20000 scientific works more than from one hundred countries [7]. According to Google Scholar, among over 70000 publications only a little more than $30 \%$ are the publications not in English [8]. Such difference in number is caused by the fact that scientists are seeking to inform bigger audience about the results of their research.

Priority of publications in the field of mining is a task for all leading experts of mining regions in the world, interested to enlighten their achievements, advanced technologies and developments by means of international scientific discourse in English. Here are some examples of journals, based on CiteScore metrics in Scopus and refined by the word "mining": Archives of Mining Sciences, Australian Mining, Canadian Mining Journal, Engineering and Mining Journal, Journal of Mining and Safety Engineering, International Journal of Rock Mechanics and Mining Sciences [URL: journalmetrics.scopus.com].

Consequently, foreign language competence allows a mining engineer from Russia, aspiring to approach high level of his/her proficiency, to enquire cutting-edge scientific and technological advances alongside with sharing one's own experience with the colleagues worldwide by means of scientific publications.

Although foreign language competence is recognized as essential for mining engineers, there are some problems, which hinder its mastering. Some of them being of general character have been disclosed in [9]. Furthermore, in case of a debate with Englishspeaking experts of the same area of research (e.g. while giving presentations at international conferences and symposiums), authors from not English-speaking countries are constantly forced to prove relevance of their scientific research caused by their lack of foreign language competence.

Moreover, it has to be admitted that to some degree there is an inevitable language barrier that causes difficulties in contact with editors of English-language journals. The authors face the following responses to the articles after their preliminary consideration "the paper is unreadable"; "poor language"; "the paper needs to be fully readable"; "a lot is unclear", etc. The reason is that in some cases publications are initially prepared in author's native language, and then they are translated into English. As a result, possible spelling errors, language interference leading to mistakes in grammar and complex sentences determine poor readability of some papers.

Besides, the authors often use machine translation that may lead to some language embarrassment, above-mentioned mistakes, misuse of terminology, etc. Machine translation can facilitate and accelerate the work on the text, but it is still far from 
perfection, not always providing positive result and constantly demanding strict control from the user.

Nevertheless, information technologies (machine translation being one of them) have proved to be useful in education. The technological level of development of communications in society has created new opportunities of information exchange during the recent years. Smartphones, tablets, computers have become a part of everyday life of an ordinary person. Electronic devices are used as an access to broad variety of resources including educational ones. In this regard we speak of "mobile learning" or "m-learning" in educational environment" [10], that is understood as an educational activity realized by means of mobile portable devices equipped with technologies of reception-transmission of information. Mobile learning modifies educational process, makes it more productive, creates new ways to present the material, and meets specific demands of students.

The above-mentioned problems predetermined the purpose of this research viz. to seek the opportunities of applying mobile technologies in mastering foreign language competence of the students majoring in mining engineering. We consider this form of education to be a regular and relevant one, because the tendency to increase the number of hours for students' independent work and to reduce the amount of classroom hours in higher education institutions makes the methods enhancing the ability of any student to browse in information space and design one's foreign language competence essential.

It is obvious that key changes in the field of teaching a foreign language in a higher education institution are closely connected with the integration of mobile devices with the proper educational applications into educational process. It is confirmed both by technical readiness of students, and their desire for independent work via mobile devices that allows them to use intensively information technology resources in foreign language teaching to master one's professional competence, to continue one's education abroad, to succeed in professional communication in a foreign language with colleagues from other countries after the graduation from a higher education institution $[11,12]$.

\section{Materials and methods}

Mobile application is a program installed and run on a smartphone or a tablet computer. We have analyzed and estimated the following mobile applications with the purpose to define their potential in the process of foreign language learning (see Table 1): Fun Easy Learn, Babbel, Duolingo, LinguaLeo and Quizlet.

The criteria of the choice of these products have been the following ones:

- cross-platforming - the versions of applications for Android and iOS;

- feedbacks - general analysis of positive reviews of users;

- number of installations - more than 1000 000;

- praises and awards by mass media for the last 5 years in categories: "Best application", "The application of the year", "The best developer", "The best startup", "The most downloaded application", etc.;

- ranking - 4,5 - 5 "stars" (on the basis of voices not less than 20.000 users in Google Play and App Store).

Thus, the potential educational characteristics of mobile applications prove to be quite promising. They are a good choice for anyone who learns foreign languages independently.

We conducted the experiment to estimate the effectiveness of studying professional English with the help of mobile applications. Moreover, our goal was to define the degree of students' satisfaction with their level of professional English after the use of mobile applications. Forty-six students learning English as a foreign language participated in the experiment in 2016-2017. Their English level ranged from beginners to intermediates. 
Table 1. The Comparative Table of Features of Mobile Applications.

\begin{tabular}{|c|c|c|c|c|c|}
\hline CRITERIA & $\begin{array}{c}\text { Fun Easy } \\
\text { Learn }\end{array}$ & Babbel & Duolingo & LinguaLeo & Quizlet \\
\hline distribution & $\begin{array}{c}\text { free } \\
\text { (chargeable } \\
\text { options) }\end{array}$ & Chargeable & free & $\begin{array}{c}\text { free } \\
\text { (chargeable } \\
\text { options) }\end{array}$ & $\begin{array}{c}\text { free } \\
\text { (chargeabl } \\
\text { e options) }\end{array}$ \\
\hline $\begin{array}{c}\text { taught } \\
\text { languages }\end{array}$ & 26 & 14 & $\begin{array}{c}\text { Depended } \\
\text { on chosen } \\
\text { language } \\
\text { pair }\end{array}$ & English & unlimited \\
\hline $\begin{array}{c}\text { taught } \\
\text { language } \\
\text { levels }\end{array}$ & $\begin{array}{c}\text { phonetics, } \\
\text { vocabulary }\end{array}$ & $\begin{array}{c}\text { phonetics, } \\
\text { vocabulary, } \\
\text { grammar }\end{array}$ & $\begin{array}{c}\text { phonetics, } \\
\text { vocabulary, } \\
\text { grammar }\end{array}$ & $\begin{array}{c}\text { phonetics, } \\
\text { vocabulary, } \\
\text { grammar }\end{array}$ & $\begin{array}{c}\text { phonetics, } \\
\text { vocabular } \\
\text { y }\end{array}$ \\
\hline $\begin{array}{c}\text { multimedia } \\
\text { audio, } \\
\text { graphics } \\
\text { graphics } \\
\text { graphics } \\
\text { graphics }\end{array}$ & $\begin{array}{c}\text { audio, } \\
\text { graphics }\end{array}$ \\
\hline $\begin{array}{c}\text { non-Latin- } \\
\text { based } \\
\text { languages }\end{array}$ & yes & yes & yes & no & yes \\
\hline $\begin{array}{c}\text { constructed/ } \\
\text { artificial } \\
\text { languages }\end{array}$ & no & no & yes & no & yes \\
\hline
\end{tabular}

We suppose tablet PCs and smartphones to be the most promising mobile devices for foreign language learning from a wide range of other mobile devices (iPhones, netbooks, laptops, iPads). Their advantages are: 1) multitasking as they allow listening to music and podcasts, watching videos, reading books, writing, searching for information via the Internet, playing games, etc., 2) small size, portability and touch screen, 3) the ability to download mobile applications for learning foreign languages (dictionaries, word simulators, language courses, podcasts, etc.).

To start with, we conducted a survey among the students to reveal whether they use tablet computers and smartphones for learning. The vast majority ( $98 \%$ of respondents) responded positively. The first place by popularity belonged to language translation programs ( $87 \%$ of respondents). Watching videos from YouTube was on the second place (35\% of respondents). And only $9 \%$ of students used special mobile applications for learning foreign languages.

Moreover, students were interviewed to identify their attitude to the possibility of using mobile technologies in teaching a foreign language at University classes. The results showed that almost all respondents $(95 \%)$ welcomed this opportunity in the classroom. When arguing their answer, the respondents noted such positive aspects of mobile applications as an increasing interest in the subject, the possibility of permanent access to the subject "on-the-go". At the same time some students did not know which mobile application could help them learn a foreign language. Another significant problem was an expensive Internet access or unavailable access to it, lack of free Wi-Fi.

Considering that the students are to study English for professional purposes (namely, mining engineering), they should master a certain professional vocabulary. However, many students face the problem of memorizing words in a foreign language. The survey on the methods students use to study foreign language vocabulary showed that the majority of students $(92 \%)$ used the drilling method.

To solve this problem, we suggested them to use the mobile application Quizlet, which is a service for creating training cards with words. It should be noted that this application 
focuses on vocabulary, its enlargement but not on an in-depth study of the language. The application aims to help a learner remember as many words as possible. This service allows:

- create your own word sets which include word cards (flashcards), adding pictures and audio files to them, or search for existing word sets on a specific topic;

- do various online exercises with word cards and even play online;

- use embedded word cards on various websites and share them in social network sites;

- listen to foreign words;

- print out word cards;

- search for word sets created by other teachers;

- study word cards even without registration;

- work with word cards in an off-line mode.

In addition to traditional two-way cards (flashcards) mode, the following modes are also available:

- $L E A R N$ (students have to print the answer);

- WRITE AND SPELL (spelling training);

- TEST (different types of tasks are allowed: write the answer, multiple choice answer, true/false answer);

- MATCH (a game where students need to match a word and its definition to make the word cards disappear);

- GRAVITY (a game in which students need to type a word, the definition of which is floating on the screen);

- QUIZLET LIVE (an online game in which students are divided into teams and compete with each other by choosing the desired translation of a word).

Students were encouraged to work with this application both in the classroom and at home in the course of out-of-class independent work. The most popular mode in the classroom has proven to be an online game mode.

\section{Results and discussion}

To assess the effectiveness of learning professional English vocabulary with the mobile application Quizlet we used the following criteria:

1) the results of vocabulary tests;

2) the results of the students' survey and interviews;

3) the results of determining students' satisfaction degree.

In the course of the experiment, we conducted one initial and three intermediate vocabulary tests, having created the word sets on the covered topics for them. The evolution of students' test results is presented in Table 2. It should be noted that Quizlet provides an opportunity for teachers to track how many students use this application.

Table 2. The Evolution of Students' Vocabulary Test Results

\begin{tabular}{|c|c|c|c|c|}
\hline CRITERIA & $\begin{array}{c}\text { Initial } \\
\text { Quizlet test }\end{array}$ & $\begin{array}{c}\text { Quizlet test } \\
\mathbf{1}\end{array}$ & Quizlet test 2 & Quizlet test 3 \\
\hline number of students & 46 & 40 & 46 & 45 \\
\hline $\begin{array}{c}\text { number of students } \\
\text { using Quizlet }\end{array}$ & 0 & 37 & 44 & 45 \\
\hline $\begin{array}{c}\text { number of words in a } \\
\text { vocabulary }\end{array}$ & 30 & 34 & 39 & 45 \\
\hline $\begin{array}{c}\text { students passed test } \\
\text { without mistakes }\end{array}$ & 9 & 24 & 38 & 40 \\
\hline $\begin{array}{c}\text { passed test without } \\
\text { mistakes (percent) }\end{array}$ & 19.5 & 52.2 & 82.6 & 86.9 \\
\hline
\end{tabular}


The data of the table revealed the improvement of students' results in vocabulary tests by $67.4 \%$. The results of the experiment have showed that the use of mobile application Quizlet in out-of-class independent work enhanced the efficiency of memorizing foreign words by students. However, according to the table not all students used the app at home. Among the reasons, they named the lack of confidence in the effectiveness of the application, the preference of traditional ways of learning.

The survey of students about the preferable Quizlet modes is shown in Table 3.

Table 3. Preferable Quizlet Modes Used by Students

\begin{tabular}{|c|c|}
\hline Quizlet modes: & Number of students (\%) \\
\hline LEARN & 35 \\
\hline FLASHCARDS & 78 \\
\hline WRITE AND SPELL & 2 \\
\hline TEST & 72 \\
\hline MATCH & 63 \\
\hline GRAVITY & 8 \\
\hline QUIZLET LIVE & 98 \\
\hline
\end{tabular}

According to the survey the most popular mode (98\%) among students is the Quizlet live mode (team play online) due to its competitive and playing character. The application allows students to be connected to an online game using a special digital code demonstrated on the screen of the teacher's device. The second place is shared between the flashcards mode $(78 \%)$ as the easiest to use and the test mode $(72 \%)$, allowing students to assess immediately the number of the words learnt (in percent). The match mode is assessed by the students as significant as two previous modes $(63 \%)$. The least popular mode is the write and spell mode due to the lack of its use when having language classes once a week.

The degree of the students' satisfaction with Quizlet application in the foreign language lessons was measured in accordance with the approach defining the degree of satisfaction as the difference between the anticipated and acquired results [13, 14]. The survey followed the experiment has showed that many students (94\%) highly appreciate Quizlet and its capabilities in mastering foreign language competence and are going to use this mobile application in the future. Nevertheless, some students (6\%) still prefer traditional methods of memorizing words.

\section{Conclusion}

The advantages of mobile applications for the process of mastering foreign language competence prove to be the following: compliance of mobile technologies with each student's personal way and tempo; feedback interaction for a student through interactive interface of mobile applications; game like training; portability of mobile technologies (optimal time and place for learning); wide range of options of mobile applications (flash cards, games, including competitive ones, online testing, etc.); opportunity to self-assess one's progress of any topic unlimited number of times. The above mentioned advantages of mobile applications in combination with traditional training techniques increase students' motivation and satisfaction with foreign language learning and promote the efficiency of mastering students' foreign language competence of mining engineers.

\section{References}

1. R.W. White, Psychological review, 66, 76-87 (1959) 
2. D.C. McClelland, American Psychologist, 28, 1-14 (1973)

3. F. Delamare Le Deist, Human Resource Development International, 8, 27-46 (2005)

4. Recommendation of the European Parliament and of the Council of 18 December 2006 on key competences for lifelong learning (Official Journal of the European Union, Bologna, 2007)

5. H. Smith, Research Trends, 6, 98-109 (2008)

6. J. Lo Bianco, PASCAL Observatory, 17, 90-99 (2007)

7. S.A. Zhironkin, K.A. Kolotov, O.V. Zhironkina, Economics and Innovation Management, 1, 4-16 (2017) DOI: 10.26730/2587-5574-2017-1-4-16

8. A.A. Khoreshok, S.A. Zhironkin, M.A. Tyulenev, G.A. Barysheva, V.Y. Blumenstein, M.C. Hellmer, S.V. Potyagailov, IOP Conf. Ser.: Mater. Sci. Eng., 142: 1, 012122 (2016)

9. O. Greenwald, R. Islamov, T. Sergeychick, E3S Web of Conferences, 21, 04012 (2017)

10. H. Crompton, A historical overview of mobile learning: Toward learner-centered education (Handbook of mobile learning, Hannover, 2013)

11. R. Salaberry, MLJ, 85, 39 (2001)

12. I. Allen, J. Seaman, Learning on demand: online education in the United States (The Sloan Consortium, Dover, 2009)

13. C. Munteanu, C. Ceobanu, C. Bobâlcă, O. Anton, Int. J. PSM, 23:2, 124-140 (2010)

14. S. Kelley, J. Donnelly, S. Skinner, J. Renov., 66:3, 315-335 (1990) 